\title{
High Performance Plasma Sputtered Fuel Cell Electrodes with Ultra Low catalytic metal Loadings
}

\author{
C. Coutanceau $^{1}$, P. Brault ${ }^{2}$, A. Caillard ${ }^{2}$, M. Mougenot ${ }^{2,3}$, S. Baranton ${ }^{1}$, A. Ennadjaoui ${ }^{3}$, \\ M. Cavarroc ${ }^{3}$ \\ ${ }^{1}$ LACCO, e-lyse, UMR n ${ }^{\circ} 6503$ CNRRS-Université de Poitiers, 40 avenue du Recteur \\ Pineau 86022 Poitiers cedex, France ; \\ Christophe.coutanceau@univ-poitiers.fr \\ ${ }^{2}$ GREMI, UMR nº606 CNRS-Université d'Orléans, BP6744, 45067 Orléans Cedex 2, \\ France ; \\ Pascal.Brault@univ-orleans.fr \\ ${ }^{3}$ Agence Innovation Made in Dreux, 4 rue Caquot, 28500 Vernouillet, France
}

Ultra-low Pt content PEMFC electrodes have been manufactured using magnetron co-sputtering of carbon and platinum on a commercial ETek_ uncatalyzed gas diffusion layer in plasma fuel cell deposition devices. Pt loadings lower than $0.01 \mathrm{mg} \mathrm{cm}^{-2}$ have been realized. The $\mathrm{Pt}$ catalyst is dispersed as small clusters with size less than $2 \mathrm{~nm}$ over a depth of $500 \mathrm{~nm}$. PEMFC test with symmetric electrodes loaded with $0.01 \mathrm{mg} \mathrm{cm}^{-2}$ led to maximum reproducible power densities as high as $0.4 \mathrm{Wcm}^{-2}$ with Nafion 212. Replacement of platinum was also realized by preparing MEAs composed of $0.01 \mathrm{mg}_{\mathrm{Pd}} \mathrm{cm}^{-2}$ for the anode and 0.01 $\mathrm{mg}_{\mathrm{Pd}} \mathrm{cm}^{-2}+0.001 \mathrm{mg}_{\mathrm{Pt}} \mathrm{cm}^{-2}$ for the cathode and Nafion 212 membrane. Power density as high as $250 \mathrm{~mW} \mathrm{~cm}{ }^{-2}$ were achieved at $80^{\circ} \mathrm{C}$, which corresponds to a specific power density of $250 \mathrm{~kW} \mathrm{~g} \mathrm{gt}^{-1}$.

\section{1-Introduction}

The great potential for the fuel cell technology to overcome the upcoming energy and resources issues in our society, justifies important research investments. Scaling up this technology in a hydrogen economy scenario would require reducing significantly the costs. DOE's objectives to be reached between 2010 and 2015 are clear: the catalyst of a fuel cell can cost no more than $4 €$ per kilowatt. If the catalyst is platinum $\left(\sim 40 € \mathrm{~g}^{-1}\right)$, as commonly used at the moment in 2011, the fuel cell performance to achieve is ca. $10 \mathrm{~kW}$ $\mathrm{g}_{\mathrm{Pt}}{ }^{-1}$. Commercial fuel cells currently used in cars have a resource efficiency of 1 or $2 \mathrm{~kW}$ $\mathrm{g}_{\mathrm{Pt}}{ }^{-1}$. The high amount of platinum makes commercial fuel cells reliable but the resource efficiency is far too low to provide a scalable transport solution. The solutions can be either to increase Pt utilization efficiency in order to decrease Pt amount in the catalytic layer or to replace platinum by a cheaper catalytic material.

Plasma sputtering deposition of Pt on carbon electrodes is a suitable technique for obtaining an efficient use of the catalyst. We have recently developed fuel cell electrodes loaded with a very small amount of platinum deposited by magnetron sputtering at the anode and at the cathode (Anode: $0.01 \mathrm{mg}_{\mathrm{Pt}} \mathrm{cm}^{-2}$; Cathode: $0.01 \mathrm{mg}_{\mathrm{Pt}} \mathrm{cm}^{-2}$ ). This deposition technique is largely used by industry and for $R \& D$ on fuel cells $[1,2]$. It has the advantage of allowing the deposition of very small quantities of material and the optimisation of its nanostructure $[3,4]$. The first part of the presentation will be devoted to 
the experimental development for Pt deposition on a gas diffusion layer and to the physicochemical deposition of the catalytic material. Then we will present and discuss the results obtained under PEMFC working conditions with a fuel cell fitted with a Nafion 212 membrane and high performance electrodes with ultra-low Pt loading down to $0.01 \mathrm{mg} \mathrm{cm}{ }^{-2}$ (Fig. 1), leading to $20 \mathrm{~kW} \cdot \mathrm{g}_{\mathrm{Pt}}^{-1}$ [5]. Analysis by Rutherford Backscattering Spectroscopy (RBS) has shown that the platinum density depth profile inside the diffusion layer is a key parameter to explain such a high efficiency [5].

Palladium appears to be a serious candidate for decreasing platinum amount in the electrode; this noble metal is currently more than twice cheaper than platinum, and because, when alloyed with platinum, it displays some catalytic activity either for the hydrogen oxidation or for the oxygen reduction [6,7] and higher tolerance toward $\mathrm{CO}$ poisoning [8]. The second part of the presentation will focus on the preparation by plasma sputtering of low catalyst loaded electrode by combining low metal loadings and replacement of platinum by a PdPt catalyst with only $10 \mathrm{wt} \%$ of platinum.

\section{2-Experimental}

Three kinds of plasma devices have been used. A first plasma magnetron sputtering device is able to produce two electrodes of size $20 \mathrm{c} 20 \mathrm{~cm}^{2}$. The deposition chamber is equipped with two rectangular targets: one of pure carbon and one of Pt0.01Carbon0.99. Deposition conditions are the followings: power $530 \mathrm{~W}$, target voltage $700 \mathrm{~V}$, target current $0.78 \mathrm{~A}$. The growth rate is $4 \mathrm{~nm} \mathrm{~min}^{-1}$. The target to substrate distance is $6.5 \mathrm{~cm}$. Targets are $45^{\circ}$ tilted with respect to the substrate. Conventional uncatalyzed E-Tek® carbon porous layers on a carbon woven web are used as substrates. The Pt and C sputtered atoms are deposited to obtain $0.01 \mathrm{mg} \mathrm{cm}^{-2} \mathrm{Pt}$ loaded electrodes. A second magnetron sputtering device is used for deposition of $0.16 \mathrm{mg} \mathrm{cm}^{-2} \mathrm{Pt}$ loaded $1 \mathrm{x} 15 \mathrm{~cm}^{2}$ electrodes from a 10 inches cylindrical pure Pt target.

The third plasma chamber has been previously detailed elsewhere [9]. Briefly, a cylindrical stainless steel low pressure TCP sputtering reactor (height $1 / 4260 \mathrm{~mm}$, diameter $1 / 4210 \mathrm{~mm}$ ) is used for the deposition of metal. The metal target, positioned at middle height, is $45^{\circ}$ tilted in front of a plane rotating substrate holder. An argon plasma is created in the chamber by an external planar $\mathrm{RF}$ antenna $(13.56 \mathrm{MHz})$ positioned on the top glass window. For Pd deposition and PdPt co-deposition, the sputtering conditions remained identical. The target is polarized at $-200 \mathrm{~V}$ and the RF power supply is adjusted between 135Wand 170Win order to keep a cathode current of $40 \mathrm{~mA}$.

The deposition conditions remained the same: $5 \mu$ bar, $5 \mathrm{sccm}$ (Ar). After $40 \mathrm{~min}$ of pure palladium deposition, the palladium anodes are loaded with $74 \mathrm{mg} \mathrm{cm} \_2$. The deposition time was varied in order to change the loading on the electrodes. All prepared catalysts are deposited on gas diffusion layers (E-TEK LT1200-W ELAT of 74\% porosity for woven web gas diffusion Layer or SIGRACET GDL 10 BB of 84\% porosity for carbon paper gas diffusion layer). The Rutherford Backscattering Spectroscopy (RBS) has been used to measure the total metal loadings.

Catalysts were characterized by transmission electron microscopy (TEM) using a Philips CM 120 microscope $(120 \mathrm{kV})$ equipped with a $\mathrm{LaB}_{6}$ filament. The mean particle size of catalyst and the morphology and structure of the electrode were determined by measuring the diameter of isolated particles using ImageJ free software. For this purpose, thin slices of electrode where cut out using an ultramicrotome fitted with a diamond blade, and placed perpendicularly to the electron beam. 
For MEA fabrication, a membrane (a Nafion 212 membrane, purchased from Quintech, Germany, noted further in the text N212) was sandwiched without prehumidification between two electrodes (an anode and a cathode of $25 \mathrm{~cm} 2$ geometric surface each) used as prepared by plasma sputtering (without Nafion_ solution addition). The MEAs is mechanically pressed at $2 \mathrm{Nm}$ torque (without hot pressing). Under our testing conditions, the pressure is manually regulated with the output valves and both the hydrogen and oxygen humidifiers are at room temperature.

\section{Results and discussion}

\section{1 characterizations of catalysts}

Figure 1 displays the SEM pictures of selected representative areas of electrodes with low platinum loading from ca. 0.003 to ca. $0.055 \mathrm{mg} \mathrm{cm}^{-2}$. Platinum is growing on the carbon particles as clusters with relatively low particle size for low loadings and form a compact thin layer for a loading of several tens of $\mu \mathrm{g} \mathrm{cm}^{-2}$.

During deposition, $\mathrm{Pt}$ atoms also diffuse in the porous layer $[3,10]$. The resulting platinum depth profiles were measured using RBS [9]. The Pt depth profile for an electrode loaded with $0.01 \mathrm{mg}_{\mathrm{Pt}} \mathrm{cm}^{-2}$, as presented elsewhere, showed that platinum penetrates down to $500 \mathrm{~nm}$ inside the diffusion layer. This rather important penetration depth is due to the deposition method, which allows depositing atoms with high kinetic energy [11,12]. A four-step process occurs during deposition: transport in the porous layer pores, adsorption on carbon particle surface, platinum diffusion on the carbon particles and Pt cluster growth. 


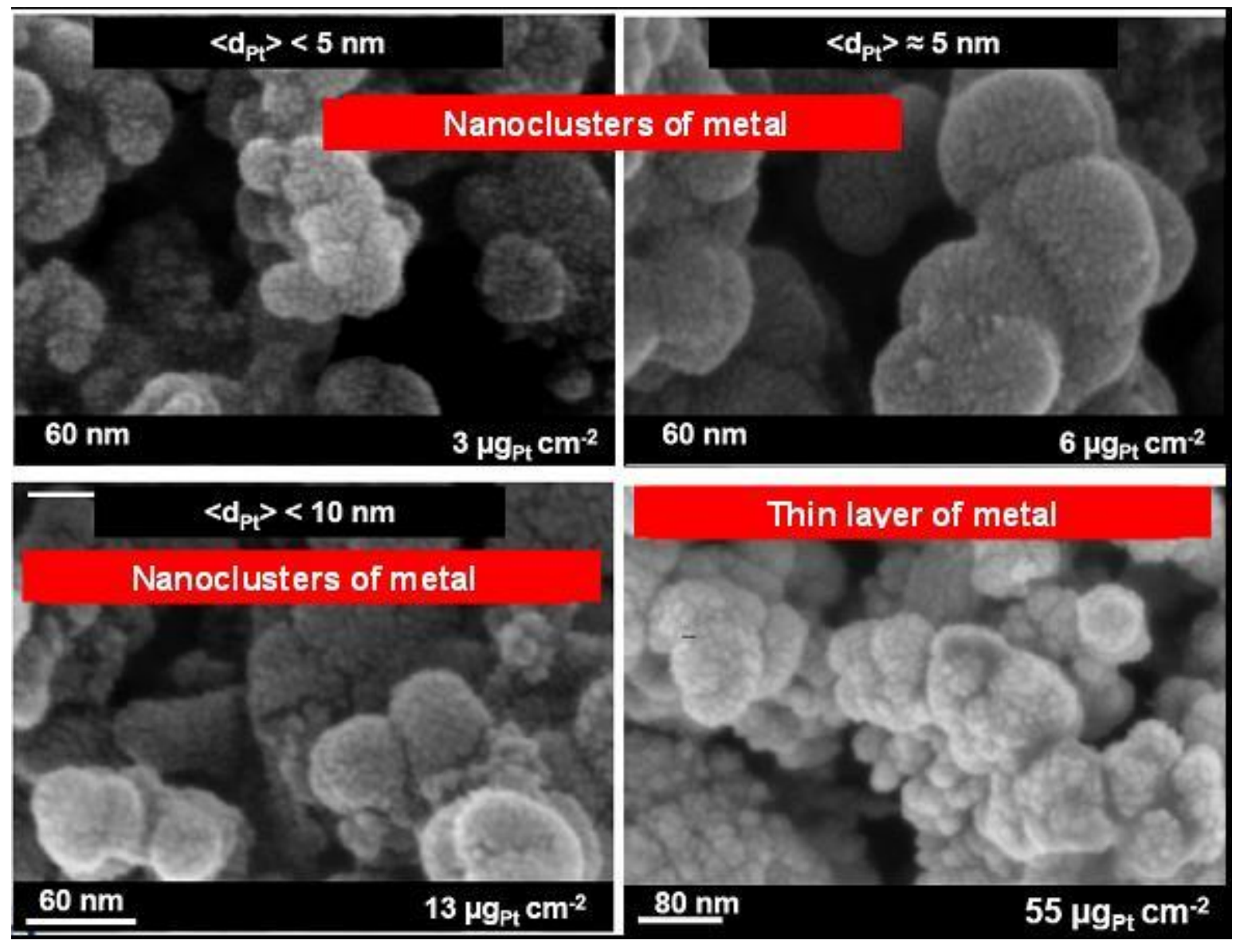

Figure 1. SEM images of electrodes with different increasing platinum loadings.

Figure 2 presents TEM image realized with different magnifications in the thickness of an electrode loaded with $0.01 \mathrm{mg} \mathrm{cm}^{-2}$ platinum. The platinum particles are deposited in an inhomogeneous manner on graphitized carbon balls with a diameters of ca. 20 to ca; $80 \mathrm{~nm}$ (figure 2a). Platinum particles are deposited on the external carbon surface which was exposed to the platinum atom flow during the plasma deposition process The penetration of platinum in the depth of the carbon support can be estimated. A very high concentration of platinum particles is observed on a thickness from 50 to $200 \mathrm{~nm}$ (Figure 2b). This platinum particle concentration decrease rapidly after the first layer of carbon spheres. The particle size in this depth range is comprised between 1 and $2 \mathrm{~nm}$ (Figure 2c). However, in a higher depth of the carbon support, bigger particles with a diameter of ca. $5 \mathrm{~nm}$ could be observed, as it is shown in Figure 2c. Such particles are very scarce, but their presence can explain the discrepancies between RBS measurements showing a penetration depth of platinum down to $500 \mathrm{~nm}$ and TEM image indicating a penetration depth of ca $200 \mathrm{~nm}$. 


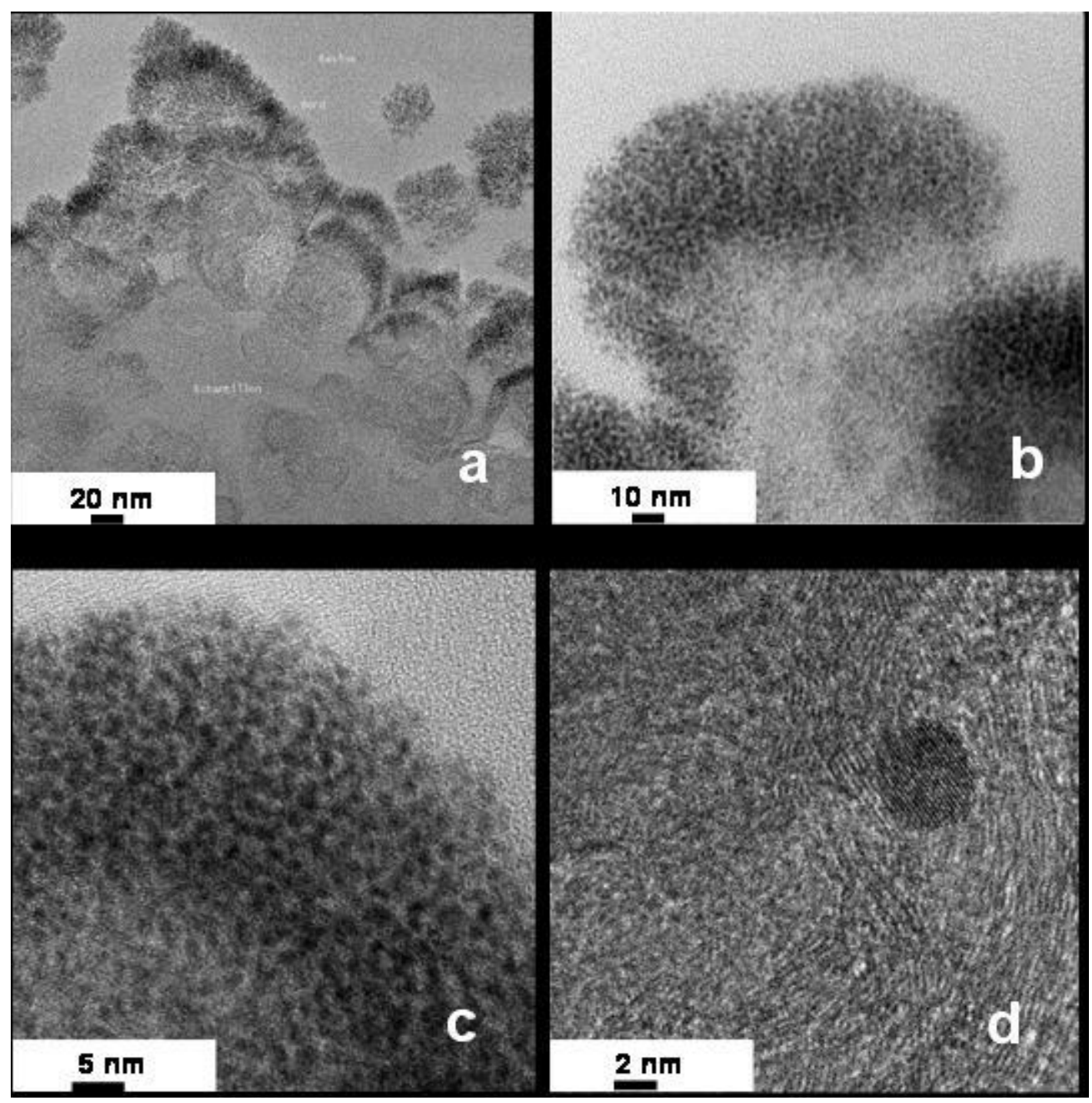

Figure 2. TEM images of slices of an electrode loaded with $0.01 \mathrm{mg} \mathrm{cm}^{-2} \mathrm{Pt}$ recorded at different magnifications.

As it can be understood from the TEM studies carried out with electrodes composed of deposited platinum on GDL, the determination of particle size from TEM images of metal sputtered on a carbon diffusion layer is very difficult to obtain and need to prepare slices of electrodes.

Palladium based electrodes were prepared and tested in order to estimate their catalytic efficiency at low loadings, and for reducing fuel cell materials costs. Electrochemical methods were then used for the estimation of the palladium particle size. Palladium deposition was electrochemically characterized in alkaline medium. Voltammogram of an electrode loaded with $0.074 \mathrm{mg} \mathrm{cm}^{-2}$ palladium is presented in Figure 3. The polarisation curves resemble to the typical one, generally recorded for polycrystalline palladium nanoparticles [13]. From the determination of the active surface area using the method of Rand and Wood [14], the particle size was estimated to be ca. 3$4 \mathrm{~nm}[15,16]$. 


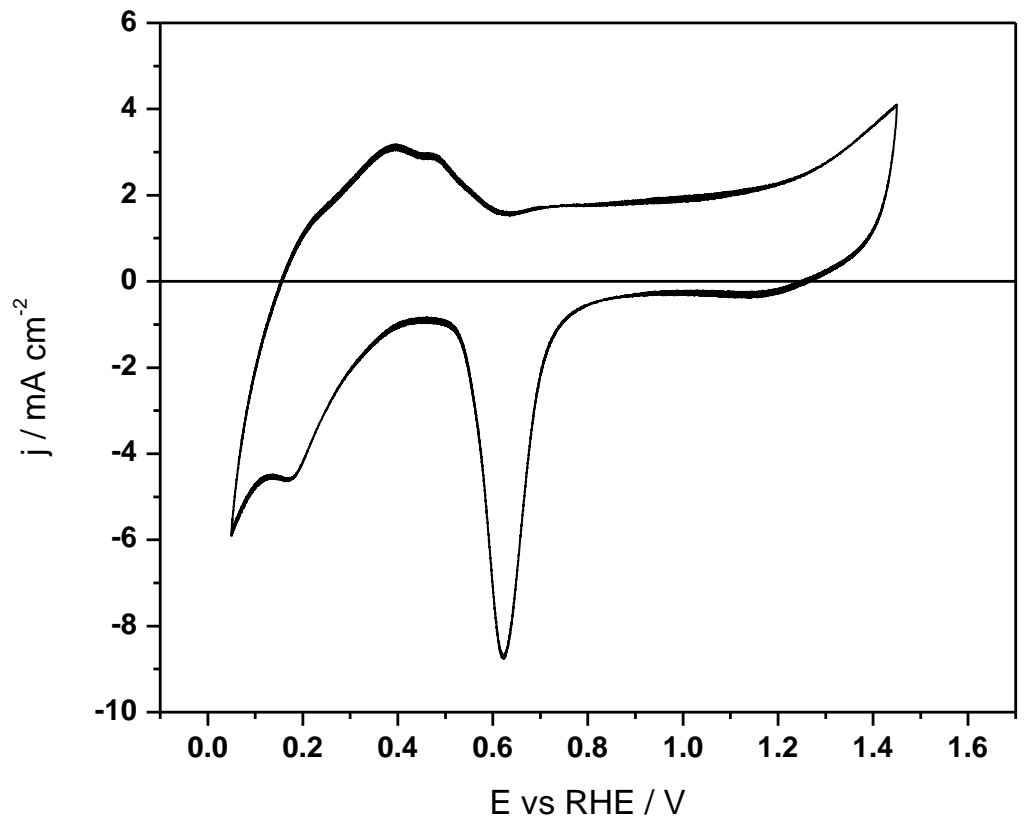

Figure 3. Cyclic voltammograms of sputtered Pd catalyst ( $\mathrm{v}=50 \mathrm{mV} \mathrm{s}{ }^{-1}, \mathrm{~N}_{2}$-saturated 1.0 $\mathrm{M} \mathrm{NaOH}$ electrolyte, $\mathrm{T}=293 \mathrm{~K})$.

\subsection{Performance of catalyst under PEMFC conditions}

Figure. 4 gives the resulting voltage/power density vs current density curves obtained using MEAs made from Nafion 212 sandwiched between both Pt sputtered electrodes loaded with $0.012 \mathrm{mg} \mathrm{cm}^{-2}$. The maximum peak powers increased from ca. $200 \mathrm{~mW} \mathrm{~cm} \mathrm{~cm}^{-2}$ at ca. $0.45 \mathrm{~V}$ to to ca. $650 \mathrm{~mW} \mathrm{~cm}^{-2}$ at $0.4 \mathrm{~V}$ with the increase of the temperature and of the reactant back pressure applied to the electrodes. At a cell temperature of $50^{\circ} \mathrm{C}$, the performance increases very drastically with the increase of the pressure from ca. $200 \mathrm{~W}$ $\mathrm{cm}-2$ at 1 bar to $320 \mathrm{~mW} \mathrm{~cm}{ }^{-2}$ at 2 bars and $500 \mathrm{~mW} \mathrm{~cm}^{-2}$ at 3 bar. This clearly indicates a strong limitation of reactant transport from the gas diffusion layer to the catalytic sites. The high density of platinum at the interface between the gas diffusion layer and the electrolytic membrane could be responsible of this behavior. The diffusion of the reactive gas (oxygen and hydrogen) through the dense platinum layer could limit their access to catalytic sites very close to the membrane, where the three-phase boundary is quantitatively and qualitatively better realized. Therefore, the increase of pressure may force gases to diffuse through the catalytic layer. This result is very interesting because it opens new research perspectives consisting in decreasing platinum film density without decreasing the number of active sites. This could be performed by tuning the plasma deposition parameters.

Temperature has also a beneficial effect on the cell electric performance. Higher power densities were achieved with a temperature of $70^{\circ} \mathrm{C}$ and a pressure of 3 bars, at least for supplied current densities lower than $1500 \mathrm{~mA} \mathrm{~cm}^{-2}$. For higher current density, it is possible that transport limitation due to the cathode flooding, which could become stronger with increasing pressure.

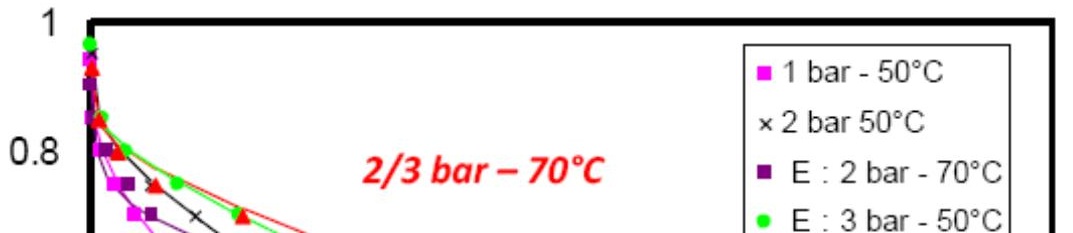


Figure 4. $E(j)$ and $P(j)$ curves obtained with a MEA made of ultra-low loaded electrodes $\left(0.012 \mathrm{mg} \mathrm{cm}^{-2}\right)$ mechanically pressed against a Nafion $212 ; 25 \mathrm{~cm}^{2}, 2 \times 12 \mu \mathrm{g}_{\mathrm{Pt}} \mathrm{cm}^{-2}$. bar $/ 50^{\circ} \mathrm{C}, \times 2 \mathrm{bar} / 50^{\circ} \mathrm{C}, 3 \mathrm{bar} / 50^{\circ} \mathrm{C}, \Delta 3 \mathrm{bar} / 70^{\circ} \mathrm{C}$ and $2 \mathrm{bar} / 70^{\circ} \mathrm{C}$ with $30 \mathrm{~min}$ rest phases between each tests. Flow rates: $\mathrm{O}_{2}=0.35 \mathrm{sccm}, \mathrm{H}_{2}=0.5 \mathrm{sccm}$.

The power density of ca. $600 \mathrm{~mW} \mathrm{~cm}^{-2}$ is reached at ca. $0.45-0.5 \mathrm{~V}$. This value is consistent with previously reported ones with conventional electrodes [17], but with 40 times less platinum. Such a level of efficiency leads to mass specific power for the different MEAs of $25 \mathrm{~kW} \mathrm{~g}_{\mathrm{Pt}}{ }^{-1}$, as determined from results in Figure 4. For explaining such results obtained without any standard preparation of the MEAs, we should mention that particle size (close to $2 \mathrm{~nm}$ ) and platinum repartition (localization of platinum close 
to the membrane electrolyte surface) in the electrodes prepared here allow realizing with high efficiency the fuel cell electrochemical reactions at both electrodes.

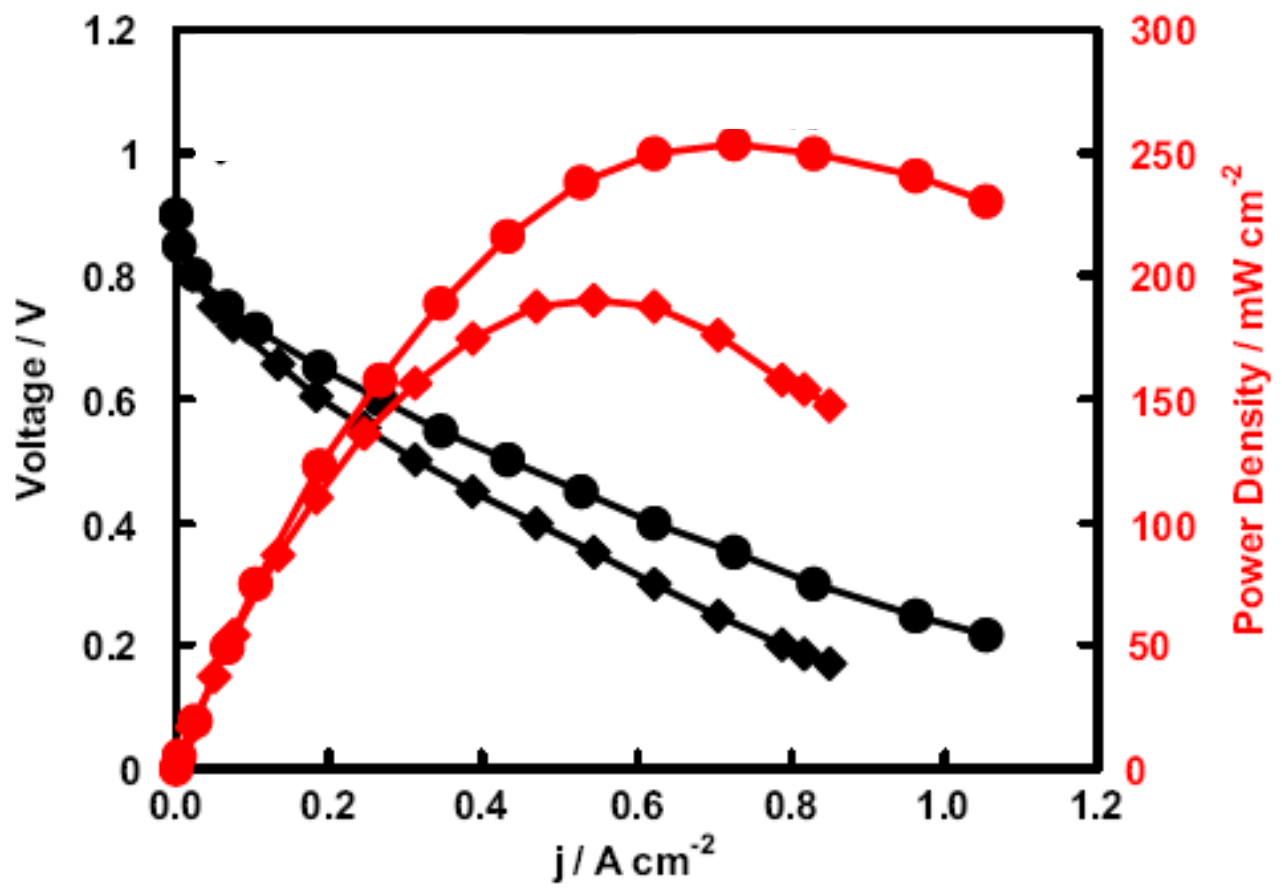

Figure 5: Performance E-j and P-j curves obtained with the MEA composed by a pure palladium anode loaded with $0.010 \mathrm{mg}_{\mathrm{Pd}} \mathrm{cm}^{-2}$ and a PdPt cathode loaded with $0.010 \mathrm{mg}_{\mathrm{Pd}}$ $\mathrm{cm}^{-2}+0.001 \mathrm{mg}_{\mathrm{Pt}} \mathrm{cm}^{-2}$, both mechanically pressed against a Nafion 212 membrane. Testing condition: $\mathrm{P}_{\mathrm{O}_{2}}$ and $\mathrm{P}_{\mathrm{H}_{2}}=3$ bars, $\mathrm{f}_{\mathrm{O}_{2}}=750 \mathrm{sccm}$ and $\mathrm{f}_{\mathrm{H}_{2}}=330 \mathrm{sccm}$, gas hydration temperatures $\mathrm{T}_{\mathrm{O}_{2}}=\mathrm{T}_{\mathrm{H}_{2}}=25^{\circ} \mathrm{C}$.

Two carbon paper GDLs have been coated by plasma sputtering with $0.01 \mathrm{mg}_{\mathrm{Pd}} \mathrm{cm}^{-2}$ for the anode and $0.01 \mathrm{mg}_{\mathrm{Pd}} \mathrm{cm}^{-2}+0.001 \mathrm{mg}_{\mathrm{Pt}} \mathrm{cm}^{-2}$ for the cathode. The MEA, involving these two electrodes and a Nafion 212 membrane, has been tested (Figure 5). A maximum power density of ca. $120 \mathrm{~mW} \mathrm{~cm}^{-2}$ at ca. $0.32 \mathrm{~V}$ was achieved for 2 bars and $50^{\circ} \mathrm{C}$ whereas $200 \mathrm{~mW} \mathrm{~cm}^{-2}$ at ca. $0.34 \mathrm{~V}$ were reached for at 3 bars and $70^{\circ} \mathrm{C}$.

When the cell temperature is increased to $80^{\circ} \mathrm{C}$, the power density increases for both low and high current density domains and reaches $250 \mathrm{mWcm}^{-2}$ at ca. $0.36 \mathrm{~V}$. It shows that the increase of temperature again seems to improve the water management in the MEA, as expected, and also improves the of reaction kinetics for both electrode catalysts. At 3 bars and $80^{\circ} \mathrm{C}$, the MEA provides a high power density can supply a high current density $\left(1.1 \mathrm{~A} \mathrm{~cm}^{-2}\right)$. Such performance corresponds to $250 \mathrm{~kW} \mathrm{~g}_{\mathrm{Pt}}{ }^{-1}$ and $12.5 \mathrm{~kW} \mathrm{~g}_{\mathrm{Pd}}{ }^{-1}$ [18]

This is a particularly good result especially at the cathode, where kinetics of oxygen reduction reaction is known to be very low. Our results are in contrast with other ones where only anode Pt mass was taken into account leading to a high specific power value close to $85 \mathrm{~kW} \mathrm{~g} \mathrm{gt}^{-1}$ [19], which has to be reduced to $1.7 \mathrm{~kW} \mathrm{~g}_{\mathrm{Pt}}{ }^{-1}$ when the Pt cathode loading is taking into account. Previous successful attempts were concerned with the use of carbon nanotubes [20] or nanofibers [21], keeping a power mass density in the range $2-5 \mathrm{~kW} \mathrm{gPt}^{-1}$. It has also to be noted that cell performance we obtained previously (400 $\mathrm{mA} \mathrm{cm}{ }^{-2}$ with electrodes loaded at $0.01 \mathrm{mg} \mathrm{cm}^{-2}$ platinum [5]) were improved 


\section{4-Conclusion}

Low platinum loading catalysts has been prepared by plasma sputtering methods. Very high cell performances were obtained, as high as $650 \mathrm{~mW} \mathrm{~cm}$-2 with symmetric electrode loaded with only $0.012 \mathrm{mg} \mathrm{cm}^{-2}$ platinum. To replace platinum at both electrodes of a PEMFC MEAs, pure palladium was used as the anode catalyst and a $\mathrm{Pd}_{0.9} \mathrm{Pt}_{0.1}$ in mass catalyst was used at the cathode. In all case, the metal depth density profiles insides the GDL and the metal loadings were determined from RBS measurements. The relations between the depth density profiles in the electrode support and the fuel cell performances could then be discussed. An optimized electrode structure has been obtained, limiting the platinum requirement, leading to a cell performance of $0.25 \mathrm{~W} \mathrm{~cm}^{-2}$ with a total catalyst loading of only $0.02 \mathrm{mg}_{\mathrm{Pd}} \mathrm{cm}^{-2}$ and $0.001 \mathrm{mg}_{\mathrm{Pt}} \mathrm{cm}^{-2}$ deposited on carbon gas diffusion

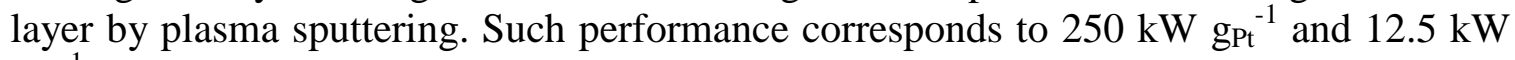
$\mathrm{g}_{\mathrm{Pd}}{ }^{-1}$.

We do not forget that the performances have to be checked under conditions closer to transportation application, i.e; air atmosphere. However, for stationary application, where hydrogen and oxygen could be supplied from the same electrolysis system, the performances of such MEA are rather interesting. The durability has also to be verified and, if necessary, improved. But, it has to be noted that each MEA was studied for several days or several weeks, without significant loss of performance. Moreover, such MEA display a very different structure than the classical ones consisting in $\mathrm{Pt}$ nanoparticles dispersed on a carbon support; in our case, the interaction carbon platinum is minimized, and interactions Pt cluster-Pt cluster is increased, which can stabilized them (bulk effect). This study aims to demonstrate that the paradigm for the MEA structure could be overpassed by developing new active layer structures leading to decrease the platinum loadings and to modify the interactions of the active sites with their environment

\section{Acknowledgments}

CNRS is acknowledged for granting the Programme Interdisciplinaire Energie "AMELI$0 \mathrm{Pt}$ " and "AMEPlas" which have permitted to obtain first interesting results. The work is now also carried out under the framework of a contract (AMADEUS) from the French National Research Agency (ANR-Emergence), funded by the French ministry of research. GdR PACS n 3339 from CNRS is acknowledged for constant support.

\section{References}

1. A. Caillard, C. Charles, R. Boswell, P. Brault and C. Coutanceau, Appl. Phys. Lett., 90, 223119, 2007.

2. A. Chen, P. Holt-Hindle, Chem. Rev, 110, 3767, 2010).

3. P. Andreazza, C. Andreazza-Vignolle, J.P. Rozenbaum, L. Thomann, P. Brault, Surf. Coat Technol., 151, 122, 2002.

4. A. L Thomann, P Braul, J P Rozenbaum, C Andreazza-Vignolle, P Andreazza, H Estrade-Szwarckopf, B Rousseau, D Babonneau and G Blondiaux, J. Phys. D: Appl. Phys., 30, 3197. 
5. M. Cavarroc, A. Ennadjaoui, M. Mougenot, P. Brault, R. Escalier, Y. Tessier, J. Durand, S. Roualdès, T. Sauvage, C. Coutanceau, Electrochem. Comm., 11, 859, 2009.

6. Y.-N. Wu, S.-J. Liao, Z.-X. Liang, L.-J. Yang, R.-F. Wang, J. Power Sources, 194, $805,2009$.

7. F. Alcaide, G. Alvarez, P. L. Cabot, O. Miguel, A. Querejeta, Int. J. Hydrogen Energy, 35, 11634, 2010,

8. A. C. Garcia, V. A. Paganin, E. A. Ticianelli, Electrochemica Acta, 53, 4309, 2008.

9. . Caillard A, Coutanceau C, Brault P, Mathias J, Léger J-M., J Power Sources, 162, 66, 2006

10. A. Caillard, P. Brault, J. Mathias, C. Charles, R.W. Boswell, Surf. Coat. Technol., 200, 391, 2005.

11. P. Brault, A. Caillard, A.-L. Thomann, J. Mathias, C. Charles, R.W. Boswell, S. Escribano, J. Durand, T. Sauvage, J. Phys. D, 37, 3419, 2004.

12. P. Brault, Ch. Josserand, J.-M. Bauchire, A. Caillard, Ch. Charles, R. W. Boswell, Anomalous diffusion mediated by atom deposition into a porous substrate, Phys. Rev. Lett. 102 (2009) 045901.

13. M. Simoes, S. Baranton, C. Coutanceau, Appl. Catal. B : environ., 93, 354, 2010.

14. A. J Rand,.and R.Woods, J. Electroanal. Chem., 36, 57.1972,

15. M. Simoes, S. Baranton, C. Coutanceau, J. Phys. Chem. C, 113, 13369, 2009.

16. M. Mougenot, A. Caillard, M. Simoes, S. Baranton, C. Coutanceau, P. Brault, Appl. Catal. B : environ., submitted.

17. S. Litster, G. McLean, J. Power Sources, 130, 61, 2004.

18. M. Mougenot, A. Caillard, P. Brault, S. Baranton, C. Coutanceau, High Performance Plasma Sputtered PdPt Fuel Cell Electrodes with Ultra Low Loading, International Journal of Hydrogen Energy 36 (2011) 8429-8434

19. A. Caillard, C. Charles, D. Ramdutt, R. Boswell, P. Brault, J. Phys. D, 42, 045207, 2009.

20. A. Caillard, C. Charles, R. Boswell, P. Brault, Nanotechnology, 18, 305603, 2007.

21. H.-T. Kim, J.-K. Lee, J. Kim, J. Power Sources, 180, 191, 2008. 